\title{
CHOLINE ESTERASE OF BLOOD CELLS AND PLASMA IN BLOOD DYSCRASIAS, WITH SPECIAL REFERENCE TO PERNICIOUS ANEMIA
}

\author{
By JEAN CAPTAIN SABINE \\ (From the Department of Physiology, University of Rochester School of Medicine \\ and Dentistry, Rochester)
}

(Received for publication July 15, 1940)

Interest in the distribution of choline esterase activity between the cells and plasma dates back a dozen years or more, but relatively little investigation has been carried out. In 1928 Galehr and Plattner (1), using a biological assay method, found that there was more choline esterase activity in human blood cells than in serum, and their finding was confirmed by Matthes (2) in 1930. The esterase activity of whole blood, hemolyzed blood and serum of man and other species was studied by Ammon and Voss (3). Human blood, whole or hemolyzed, was found to be more active than serum, and dog blood less active than serum. The distribution of esterase activity between blood cells and serum of defibrinated blood was studied by Stedman and Stedman (4) in normal persons and in a number of species of animals, and by Stedman and Russell (5) in twelve myasthenia gravis patients and a group of muscular, neuromuscular and psychopathic cases. They found marked species differences, both as to choline esterase activity and as to distribution of activity between plasma and cells. In the normal human they found that the cells have consistently more activity than the plasma. Their myasthenia gravis patients showed a decrease in plasma esterase and an esterase value for cells approximating the normal values. In the myopathic and psychopathic group they found a general lowering of plasma esterase and a variety of disturbances of the esterase distribution.

That the activity of the formed elements of the blood resides chiefly in the red cells is generally accepted. Ginsberg et al. (6) found that washed pus cells showed no esterase activity. In April, 1940, Alles and Hawes reported qualitative differences between the choline esterase of blood cells and of plasma in their behavior toward different substrates and toward different concentrations of the same substrate. Further reference to this work will be made in the discussion.
Information concerning the esterase activity in anemias is very meager. Antopol et al. (7) list a case of secondary anemia and one of acute hemolytic anemia in a series of cases of jaundice and liver disease in which there was a general lowering of serum esterase. Milhorat (8) reports values for a long list of varied clinical conditions. Among them are a case of primary anemia and one of acute myeloid leukemia. The degree of anemia is not stated for either case. The primary anemia showed a normal esterase activity in the serum; the leukemia, a markedly lowered value. He states that no correlation was found with red cell count or hemoglobin in this series.

As a tentative investigation, preliminary to the present study, determinations were made on the esterase activity of two dogs in the laboratory of the Pathology Department, through the courtesy of Dr. Sidney Madden and Mr. Albert Rowe. These dogs were made anemic by repeated phlebotomy. In the normal period the dogs were found to have an appreciably higher esterase activity in the plasma than in the whole blood. This is in accord with the results of Ammon and Voss (3) and with unpublished results of Dr. Fenn in this laboratory. As the hematocrit fell, a lowering of the plasma esterase was observed. A slight fall in the whole blood esterase occurred, but the calculated value for blood cells showed a marked rise. On this lead it was decided to investigate the esterase activity of the cells and plasma of patients with anemias of various etiologies.

\section{METHOD}

Measurement was made of the rate of production of acetic acid from an excess of acetyl choline substrate by the enzyme present in a measured amount of plasma or whole blood. A continuous titration method was used, similar to Glick's modification (9) of the method of Stedman, Stedman and Easson (10), and similar to the 
method of Alles and Hawes (11). Blood and plasma were measured in a capillary pipette calibrated to hold 0.202 cc. This amount was delivered into $95 \mathrm{cc}$. of distilled water in a $100 \mathrm{cc}$. beaker, and the pipette was washed back seven times with this water. The beaker was then placed in a water bath, the temperature of which was kept between 24 and $26^{\circ} \mathrm{C}$. and as near as possible to $25^{\circ} \mathrm{C}$. The temperature of the experimental solution was read at intervals by means of a thermocouple and galvanometer. Into the solution also dipped the end of a microburette, a glass electrode, a glass stirring rod with propeller, run by a special telechron motor at 300 r.p.m., and a short agar-saline bridge to a small vessel also immersed in the bath, and containing 0.85 per cent $\mathrm{NaCl}$ solution and the calomel electrode. The electrodes were led off to a Beckman $\mathrm{pH}$ meter by shielded leads. The water bath and electrodes were further shielded by a sheet metal cage with wire door, which also offered some protection from temperature changes.

The salt bridge was necessary because esterase activity is affected by $\mathrm{K}$ ions (12). It was found by checking with a standard buffer solution that the salt bridge made the solution read $0.15 \mathrm{pH}$ more acid than its true $\mathrm{pH}$, in the neighborhood of $\mathrm{pH} 7.50$. This difference was found to be constant, and the meter was just as steady with the bridge as without it. A reading of 7.50 was used as the end-point in these titrations, so the true $\mathrm{pH}$ was 7.65. This was also checked by comparison with indicators.

After reaching temperature equilibrium, the solution containing esterase was brought to approximately $\mathrm{pH} 7.6$ (as read on the meter) with dilute $\mathrm{NaOH} ; 1.0$ cc. of a 1 per cent solution of acetyl choline chloride (HoffmannLaRoche) in $M / 750$ phosphate buffer was added, and enough water to bring the volume to $100 \mathrm{cc}$. The indicator dial of the meter was kept set at 7.50. The time when the alkalinized solution crossed the 7.50 mark was clocked with a stop-watch. Then standardized $\mathrm{NaOH}$ approximately $0.02 \mathrm{~N}$ was run in from the microburette to maintain the solution between $\mathrm{pH} 7.48$ and 7.52 as read on the meter. At the end of approximately fifteen minutes the solution was made more alkaline, about $\mathrm{pH}$ 7.55 , and the time again clocked when the needle passed $\mathrm{pH}$ 7.50. The rate of hydrolysis was found to be constant over a period of one hour in preliminary experiments. All determinations were done in duplicate.

Temperature corrections were made from a calibration curve determined experimentally. The corrections were never in excess of 1 per cent of the normal rates and 5 per cent for the very low rates. This arrangement was considered satisfactory since the changes reported are large. The difficulty of putting a thermostatted water bath in the cage has made it impracticable to introduce this feature for the present.

Blanks were run on normal and abnormal blood or plasma and buffer, and on acetyl choline with its buffer, and each proved to have a small rate of acidification (the acetyl choline solution slightly greater than the enzyme preparation) amounting to 1 to 2 per cent of the rate usually observed for enzyme-substrate preparations.
Since correction would tend to accentuate rather than diminish the contrasts which are being reported, the figures have not been corrected for this small error.

Blood samples were taken from patients in the hospital and clinic, and from staff members of both sexes and various ages for controls. No attempt was made to take all blood samples at the same time of day, as many of the patients were acutely ill and were treated or transfused very soon after admission, and others were seen in the clinics at various times of day. This is probably of no significance, as it has been shown that no diurnal or prandial cycle is demonstrable $(13,14,15)$. Ten cc. of venous blood was taken into two oxalate bottles. Plasma and whole blood for esterase determinations were preserved with thymol, which was shown in preliminary experiments to be without effect on the esterase rate, and placed in the icebox. All samples were run within fortyeight hours, and the observation of others $(11,13,16)$ that preservation for several days does not alter the esterase activity has been confirmed. Hematocrit determinations and red cell counts were made in the usual way. Hemoglobin was determined with a Sahli hemoglobinometer. Reticulocytes were counted after staining wet preparations with brilliant cresyl blue.

\section{Calculations aNd DEsignations}

Esterase activity is expressed as cc. of $0.01 \mathrm{~N} \mathrm{NaOH}$ required to neutralize the acetic acid formed from acetyl choline per minute per cc. of blood, plasma or cells at $\mathrm{pH} 7.65$ and temperature $25^{\circ} \mathrm{C}$. This value is given the designation $E$. The cell $E$ as measured was, on the average, slightly lower than the calculated cell $E$, and the standard deviation of a number of determinations on a single sample was somewhat greater. The results of Alles and Hawes, which were published after the work reported here was finished, indicate that this may be due to the lower $\mathrm{NaCl}$ content of the cell preparations. The whole blood and plasma values are probably more valid than the measured cell values, so the latter have been discarded and only the calculated values used.

Activity of the cells is referred to as cell $E$ when activity per cc. of cells is meant. Since the mean corpuscular volumes (M.C.V.) vary considerably under conditions of anemia and reticulocyte response, it was found convenient to express a "mean corpuscular esterase," designated M.C.E. This value was found by multiplying the cell $E$ by the M.C.V. in cc. (or the M.C.V. in cu. micra as used clinically $\times 10^{-22}$ ). For convenience this value is expressed multiplied by $10^{20}$.

\section{STATISTICAL TREATMENT}

The mean values for six normal persons are given in Table I. No other value was regarded as significantly different from the normal unless this was indicated by the " $t$ test" of Fisher (17) with a probability of at least 98 per cent.

The heterogeneity of the group in regard to 
TABLE I

Choline esterase of whole blood, plasma and blood cells of patients with anemia and of normal persons

\begin{tabular}{|c|c|c|c|c|c|c|c|c|c|}
\hline \multirow{2}{*}{$\begin{array}{c}\text { Case } \\
\text { number }\end{array}$} & \multirow{2}{*}{ Condition } & \multirow{2}{*}{$\begin{array}{c}\text { Red blood } \\
\text { cells }\end{array}$} & \multirow{2}{*}{$\underset{\text { crit }}{\text { Hemato- }}$} & \multirow{2}{*}{$\begin{array}{l}\text { Reticulo- } \\
\text { cytes }\end{array}$} & \multirow{2}{*}{$\begin{array}{l}\text { Hemo- } \\
\text { globin }\end{array}$} & \multicolumn{4}{|c|}{ Choline esterase activity* } \\
\hline & & & & & & $\begin{array}{l}\text { Whole } \\
\text { blood }\end{array}$ & Plasma & Cell & $\underset{\times 10^{10}}{\text { M.C.E. }}$ \\
\hline $\begin{array}{r}1 \\
2 \\
3 \\
4 \\
5 \\
6 \\
7 \\
8 \\
9 \\
10 \\
11 \\
12\end{array}$ & $\begin{array}{l}\text { Hemorrhage } \\
\text { Hemorrhage } \\
\text { Leukemia } \\
\text { Leukemia } \\
\text { Hodgkin's } \\
\text { Erythroblastic anemia } \\
\text { Macrocytic anemia } \\
\text { Plummer-Vinson syndrome } \\
\text { Microcytic anemia } \\
\text { Polycythemia vera } \\
\text { Treated pernicious anemia } \\
\text { Treated pernicious anemia } \\
\text { Normal } \\
\text { Normal } \\
\text { Normal } \\
\text { Normal } \\
\text { Normal } \\
\text { Normal }\end{array}$ & $\begin{array}{c}\text { millions } \\
2.2 \\
2.0 \\
1.3 \\
1.8 \\
2.0 \\
1.6 \\
2.3 \\
5.1 \\
4.6 \\
5.8 \\
4.4 \\
5.0 \\
5.7 \\
5.7 \\
4.1 \\
5.2 \\
4.9 \\
5.7\end{array}$ & $\begin{array}{c}\text { per cent } \\
19.8 \\
19.6 \\
13.7 \\
16.1 \\
20.3 \\
13.3 \\
24.7 \\
34.8 \\
32.3 \\
34.5 \\
45.2 \\
41.3 \\
50.0 \\
42.3 \\
36.1 \\
44.4 \\
40.2 \\
45.8\end{array}$ & $\begin{array}{c}\text { per cent } \\
6.8 \\
12.3 \\
0.2 \\
0.3 \\
0.3 \\
25.0 \\
4.4 \\
1.5\end{array}$ & $\begin{array}{c}\text { grams } \\
6.1 \\
6.3 \\
4.0 \\
4.6 \\
7.0 \\
2.5 \\
6.0 \\
7.2 \\
16.6 \\
15.0 \\
13.3 \\
14.3 \\
15.0 \\
14.8 \\
13.0 \\
14.3 \\
13.9 \\
14.8\end{array}$ & $\begin{array}{l}0.264 \\
0.264 \\
0.190 \\
0.216 \\
0.184 \\
0.184 \\
0.225 \\
0.312 \\
0.398 \\
0.324 \\
0.391 \\
0.254 \\
0.407 \\
0.343 \\
0.319 \\
0.341 \\
0.333 \\
0.273\end{array}$ & $\begin{array}{l}0.102 \\
0.100 \\
0.099 \\
0.112 \\
0.079 \\
0.106 \\
0.081 \\
0.148 \\
0.177 \\
0.171 \\
0.224 \\
0.165 \\
0.153 \\
0.175 \\
0.183 \\
0.188 \\
0.219 \\
0.139\end{array}$ & $\begin{array}{l}0.919 \\
0.944 \\
0.809 \\
0.794 \\
0.603 \\
0.691 \\
0.663 \\
0.693 \\
0.867 \\
0.615 \\
0.593 \\
0.391 \\
0.660 \\
0.577 \\
0.582 \\
0.532 \\
0.496 \\
0.437\end{array}$ & $\begin{array}{l}0.823 \\
0.901 \\
0.823 \\
0.695 \\
0.603 \\
\\
0.723 \\
0.473 \\
0.613 \\
0.369 \\
0.610 \\
0.321 \\
0.577 \\
0.430 \\
0.494 \\
0.452 \\
0.422 \\
0.371\end{array}$ \\
\hline \multicolumn{2}{|c|}{ Average of normals } & & & & & 0.336 & 0.176 & 0.547 & 0.484 \\
\hline
\end{tabular}

* Choline esterase activity $(E)$ is expressed as cc. of $0.01 \mathrm{~N} \mathrm{NaOH}$ required to neutralize the acetic acid formed from acetyl choline per minute per cc. of blood, plasma or cells at pH 7.65 and temperature $25^{\circ} \mathrm{C}$.

$\dagger$ M.C.E. (the esterase activity per cell) is found by multiplying the cell $E$ by the M.C.V. in cc. This value is expressed multiplied by $10^{10}$.

age, sex and nutrition is not considered to be of importance, since it has been found that esterase activity of the blood is not affected by age, sex, weight, menstruation, pregnancy, exercise, diet (13), or by fasting $(3,13)$.

\section{RESULTS}

A group of fifteen cases and six normals was studied: Nine cases of anemia other than Addisonian pernicious anemia, one case of polycythemia vera, two cases of adequately treated pernicious anemia, and three cases of severe, practically untreated pernicious anemia which were followed through treatment to partial or complete restoration of the blood picture to normal.

Plasma esterase. The values for plasma $E$ were in accord with those reported by others, who have found low esterase in serum of patients who were debilitated or comatose from a variety of causes $(3,7)$. All of the cases with markedly low hematocrit and red count showed low plasma esterase activity. One case of idiopathic hypochromic anemia with Plummer-Vinson syndrome showed a normal plasma esterase, although she had only 7.2 grams of hemoglobin, with a red count of $5,100,000$ and a hematocrit of 34.8 per cent. A microcytic secondary anemia with normal red count and lowered hematocrit showed normal esterase values throughout. The adequately treated pernicious anemia patients had normal or slightly high plasma esterase values. It may be noted that the patient (Case 11) with a slightly high plasma value had marked, long-standing combined system disease. No correlation was observed between the degree of lowering of the plasma esterase and the severity of the anemia or degree of debilitation, but the absence of correlation is probably not significant because there was an inadequate number of cases and not enough of moderate severity. Only one pernicious anemia patient could be followed through to complete restoration of the blood picture to normal. His plasma esterase gradually rose, to attain a normal value when he was seen in clinic with a hematocrit of 46.6 per cent and a red count of 4,540,000.

Whole blood esterase. All of the patients with markedly lowered hematocrit and red cell count showed significantly lowered whole blood esterase 
activity, and this was in a general way related to the state of debilitation of the patient. Since the whole blood values represent a combination of plasma and cell esterase, discussion of the cell esterase values will be preferable to discussion of the whole blood values.

Cell esterase and mean corpuscular esterase. There appears to be an increase of the cell $E$ and M.C.E. in anemias if the bone marrow is not pathological. This was best observed in two cases of acute hemorrhage from peptic ulcer (Cases 1 and 2), both having the cell $E$ approximately 170 per cent of the mean normal value, and the M.C.E. 170 per cent and 190 per cent, respectively, of the mean normal value. Two cases of leukemia also had high esterase in the cells, one chronic lymphoid leukemia (Case 3) and one chronic myeloid leukemia (Case 4). These patients both had severe anemia of long standing without any reticulocyte response at the time they were examined. Both showed cell $E$ approximately 150 per cent of the mean normal value. The marrow of both was presumably infiltrated with leukemic cells, and hence not really free of pathology, but insofar as the marrow was able to withstand the mechanical interference, its functioning probably approximated the physiological.

A macrocytic anemia of undetermined etiology (Case 7), not responding to liver therapy, showed a normal cell $E$ with a significantly high M.C.E. A moribund child with erythroblastic anemia (Cooley's) showed a moderate but statistically significant rise in cell $E$. Due to the extreme heterogeneity of the cells, it seemed meaningless to compute an M.C.E. for this case. A moribund young woman (Case 5), diagnosed clinically as aplastic anemia and found at autopsy to be a case of Hodgkin's disease with extensive invasion of the marrow, showed a low plasma $E$ and a normal cell $E$ and M.C.E. A case of idiopathic microcytic hypochromic anemia (Case 8) had an elevated cell $E$ but a normal M.C.E. A case of microcytic anemia secondary to long-standing rheumatic infection (Case 9) had normal plasma and whole blood $E$, but markedly elevated cell $E$ and slightly elevated M.C.E. A case of polycythemia vera (Case 10) with normal red count maintained by repeated phlebotomy had normal values throughout. Unfortunately, no case of untreated polycythemia vera was available for comparison. Of the two adequately treated pernicious anemias, one had normal values throughout; the other had a normal cell $E$ and a significant elevation of the M.C.E.

The values for all of these cases are given in Table I, and the relevant clinical data immediately follow :

Case 1, Number 81157,1 was a fifty-eight year old Italian man, with an ulcer history of fifteen years' duration, but with no acute episodes since 1938. Diagnosis was acute hemorrhage from peptic ulcer. The response to transfusion, iron therapy and smooth diet was satisfactory.

Laboratory data: Erythrocytes 2,200,000. Hemoglobin 6.1 grams. Leukocytes 7,100 with normal differential and smear. Hematocrit 19.8 per cent. Reticulocytes 6.8 per cent. Urine $1+$ albumin. Stool tarry, $4+$ guaiac, many red and white blood cells. Blood Wassermann negative.

Case 2, Number 159058,1 was a seventy-five year old American white man, first seen in 1939, when diagnosis was acute alcoholism and posterolateral sclerosis. On present admission the patient was brought in by the police, having lost consciousness and fallen. There had been incontinence but no convulsions. There was a history of anorexia during the past few weeks, but tarry stools and vomiting were denied. Admission diagnosis was acute hemorrhage from peptic ulcer, and posterolateral sclerosis. Response to transfusion, iron therapy and smooth diet was satisfactory.

Laboratory data: Erythrocytes 2,050,000. Hemoglobin 6.3 grams. Leukocytes 9,800 with normal differential and smear. Hematocrit 19.6 per cent. Reticulocytes 12.3 per cent. Urine negative. Stool tarry, $4+$ guaiac, many red and white blood cells. Blood Wassermann negative.

Case 3, Number 157791,1 a Polish-American man of fifty-seven, was admitted with complaint of progressive weakness, palpitation and dyspnea. Diagnosis was chronic lymphoid leukemia and secondary anemia.

Laboratory data: Erythrocytes 1,330,000. Hemoglobin 4.0 grams. Leukocytes 38,000 with 98 per cent lymphocytes. Smear: achromia, anisocytosis and poikilocytosis. Hematocrit 13.7 per cent. Reticulocytes 0.2 per cent. Urine and stool negative. Blood Wassermann negative. Sternal biopsy: infiltration of the marrow with lymphoid cells.

Case 4, Number 53588,1 an American white woman of fifty-eight, had a long history in this hospital and clinic, with diagnosis of chronic myeloid leukemia. When seen in clinic, at the time this blood sample was taken, the patient was ambulatory but actually appeared moribund. She was exceedingly pale and scarcely able to walk. The spleen was down to the pelvis, and the liver down

1 These numbers are the hospitalization numbers of patients at Strong Memorial and Municipal Hospitals, Rochester, N. Y. 
1 finger's breadth below costal margin. She was admitted to the hospital, but was discharged against advice and died at home about one month later.

Laboratory data: Erythrocytes 1,800,000. Hemoglobin 4.6 grams. Leukocytes 157,000 with 92 per cent myeloid cells, the Schilling count showing a striking shift to the immature types. Hematocrit 16.1 per cent. Reticulocytes 0.3 per cent. Urine and stool negative. Blood Wassermann negative.

Case 5, Number 149368,1 a twenty-two year old American negress, was admitted in a prostrated and semicomatose condition. Clinical diagnosis was aplastic anemia, with question of aleukemic leukemia or agranulocytic angina. The patient died a few days after admission, and autopsy showed extensive Hodgkin's disease involving the mediastinal and abdominal lymph nodes and the marrow.

Laboratory data: Erythrocytes 2,010,000. Hemoglobin $\mathbf{7 . 0}$ grams. Leukocytes 900 with 90 per cent lymphocytes. Hematocrit 20.3 per cent. Reticulocytes 0.3 per cent. Urine and stool negative. Blood Wassermann negative.

Case 6, Number 57332,1 an eight-year old Italian girl, with a long history in this hospital, was diagnosed in 1937 as erythroblastic anemia. On her last admission the patient was extremely undernourished, pale, irritable and apparently moribund. There was marked cardiac decompensation. The liver was down to the umbilicus, and the spleen to the pelvis. Massive ascites was present, and the viscera could only be felt after paracentesis. The patient died about two weeks after this sample was taken. Discharge diagnosis was erythroblastic anemia, myocardial insufficiency, subacute hemolytic streptococcus peritonitis and malnutrition.

Laboratory data: Erythrocytes 1,600,000. Hemoglobin 2.5 grams. Leukocytes 29,000 with 78 per cent polymorphonuclears. Smear: 50 nucleated red cells per 100 white cells; marked anisocytosis, poikilocytosis, fragmentation and basophilia. Hematocrit 13.3 per cent. Reticulocytes 25 per cent. Ascitic fluid: 2.06 per cent protein, $30 \mathrm{mgm}$. per cent nonprotein nitrogen. Hemolytic streptococcus on culture. Blood culture negative. X-rays of the skull: changes typical of erythroblastic anemia. Urine and stool negative. Blood Wassermann negative.

Case 7, Number 55711,1 an Italian woman of fiftyeight, was admitted by Emergency complaining of abdominal pain and diarrhea of one week's duration. The skin appeared yellow. The tongue was smooth and atrophic. Admission diagnosis was pernicious anemia. Liver therapy produced no change in the reticulocyte count. A number of studies were carried out, but the patient was discharged to clinic with a diagnosis of macrocytic anemia of unknown etiology, latent syphilis, chronic leukopenia of unknown cause and arteriosclerotic heart disease.

Laboratory data: Erythrocytes 2,270,000. Hemoglobin 6.0 grams. Leukocytes 3,300 with normal differential. Smear: anisocytosis, poikilocytosis, rare megaloblasts and occasional stippling. Hematocrit 24.7 per cent. Re- ticulocytes 4.4 per cent. Urine and stool negative. Blood Wassermann positive. Icterus index 11 . Gastric analysis: no free $\mathrm{HCl}$ fasting, after alcohol and after histamine.

Case 8, Number 1868,1 an American Jewish woman of forty-five, was admitted to the hospital with complaint of pain in the right side, difficulty in swallowing and constipation. The tongue was red and smooth. The finger and toe nails were spoon-shaped. The liver was palpable just below the costal margin. Diagnosis was idiopathic hypochromic microcytic anemia with PlummerVinson syndrome.

Laboratory data: Erythrocytes 5,100,000. Hemoglobin 7.2 grams. Leukocytes 5,600 with normal differential and hypochromic smear. Hematocrit 34.8 per cent. Reticulocytes 1.5 per cent. Urine and stool negative. Blood Wassermann negative. Gastric analysis: no free $\mathrm{HCl}$ fasting, after alcohol and after histamine. G.I. series: megacolon.

Case 9, Number 163127,1 an English woman of fortyfour, was admitted with polyarthritis of two weeks' duration, with a past history of rheumatic fever and arthritis. The heart was markedly enlarged, with systolic murmurs. Diagnosis was acute rheumatic fever, rheumatic pleurisy, rheumatic heart disease, chronic tonsillitis and secondary anemia.

Laboratory data: Erythrocytes 4,570,000. Hemoglobin 16.6 grams. Leukocytes 16,000 with normal differential. Smear: marked poikilocytosis, with some cigar-shaped cells. Hematocrit 32.3 per cent. Urine and stool negative. Blood Wassermann questionable on repeated examinations; spinal fluid Wassermann negative. Sedimentation rate $18 \mathrm{~mm}$. per hour.

Case 10, Number 71716,1 was an American white woman of forty-five, with a history of polycythemia vera, mitral insufficiency and epilepsy since 1933. She had been hospitalized on many occasions and treated with phenylhydrazine and by phlebotomy. Her red cell count had been as high as 7,300,000, with 24 grams of hemoglobin. The spleen had been palpable at all times, extending as low as 4 finger's breadth below the costal margin. At the time when this blood sample was taken, the patient was seen in clinic, with red blood cells $5,770,000$, hemoglobin 15.0 grams, hematocrit 34.5 per cent and reticulocytes 0.8 per cent.

Case 11, Number 162882,1 an Irish American man of fifty, a known pernicious anemia case, treated over several years with intramuscular liver, had marked neurological symptoms and signs. At the time when this blood sample was taken, the patient was seen in clinic, with red cell count 4,380,000, hemoglobin 13.3 grams, and hematocrit 45.2 per cent.

Case 12, Number 53987,1 an American white woman of forty-four, had a history of pernicious anemia and several bouts of intestinal obstruction. The blood picture had been maintained by liver therapy in the clinic. At 
the time of this sample, the red blood cells were $5,030,000$, the hemoglobin 14.3 grams, and the hematocrit 41.3 per cent.

\section{Addisonian pernicious anemia}

Three patients first seen with severe, untreated or practically untreated pernicious anemia, were studied. One was followed through to complete restoration of the blood picture to normal, one to partial recovery, and the third could be followed for only two weeks.

Case 13, Number 161475,1 an American white man of sixty, was admitted by Emergency on January 23, 1940, in a state of prostration, dyspnea and extreme pallor. For four months prior to admission he had been growing progressively weaker, and had been bed-ridden for one month. Increasing pallor, with recent appearance of a yellow tinge, had been noted. Paresthesias of the hands and feet had been present for two months. A small amount of treatment with liver preparations by mouth had been received, but no intramuscular therapy.

Physical examination: The patient was a well-developed, poorly nourished, thin, weak and exhausted man of sixty, with a lemon-yellow skin and extreme pallor, appearing acutely ill. The temperature was $38^{\circ} \mathrm{C}$., the pulse rate 112 , the respirations 29 , and the blood pressure 108/58. The fundi showed old and new flame-shaped hemorrhages, cotton-wool exudates and very yellow discs. The tongue was smooth and red. The heart was somewhat enlarged, and a systolic murmur was heard. The liver was 2 finger's breadth below the costal margin. Neurological examination was negative except for diminished vibratory sense in the extremities.

Laboratory data: Erythrocytes 1,050,000. Hemoglobin 3.2 grams. Leukocytes 3,500 with normal differential. Smear: marked poikilocytosis, anisocytosis and basophilia, many nucleated red cells and some megaloblasts. Hematocrit 11.0 per cent. Reticulocytes 1.2 per cent. Urine and stool negative. Blood Wassermann negative. Icterus index 14. Gastric analysis: no free $\mathrm{HCl}$ fasting, after alcohol and after histamine. Electrocardiogram: changes compatible with coronary disease.

Course: This patient had a smooth course, with ideal response to treatment. During the first three days the patient received $1 \mathrm{cc}$. daily of "Reticulogen," and during the remaining twenty-four days of his stay in the hospital he received a total of 2 cc. The blood picture improved steadily and rapidly, as did the clinical condition. Reticulocytes rose to 36 per cent on the fifth day, and gradually fell. On February 20, 1940, he was discharged to clinic. At the time of discharge the red cell count was $3,400,000$, and the hemoglobin 9.9 grams. The heart was decreased in size. Improvement continued, the patient receiving $1 \mathrm{cc}$. of "Reticulogen" intramuscularly once a week in the clinic. When seen on March 12, 1940, the red cell count was $4,540,000$, and the hematocrit 46.6 per cent. Diagnosis was pernicious anemia with subacute combined system disease.

When first seen, on admission, this patient had an amazingly low choline esterase activity of both the blood and plasma. The plasma $E$ was 0.058 , or 30 per cent of the mean normal value, and the whole blood $E$ was 0.083 , or 25 per cent of the mean normal value. This is the only case in the series in which the cell $E$ and M.C.E. were significantly below normal. Values of 0.278 and 0.292 , respectively, or 51 per cent and 60 per cent of the mean normal values, were found. On the fourth day of treatment, when the hematocrit had risen from 11.0 per cent to 22.0 per cent, and the red cell count had risen from $1,050,000$ to 1,630 ,000 , the plasma $E$ was not significantly altered, but the whole blood $E$ was 0.163 , double the value on admission; the cell $E$ was normal and the M.C.E. significantly above normal. The values for plasma, whole blood and cells continued to rise. By the eighth day the M.C.E. had reached the value of $0.810,270$ per cent of the initial value and 170 per cent of the mean normal value. The M.C.E. leveled off at about this value, reaching 0.856 on the twenty-first day. The cell $E$ continued to rise until the twenty-seventh day, when the patient was discharged. The discrepancy between the responses of cell $E$ and M.C.E. is directly related to the changing mean corpuscular volume. The esterase per cell reached a maximum fairly early; then, as the cells became more numerous and smaller, the esterase per unit volume of cells became larger without much change in the activity per cell. The whole blood $E$ reached a normal value on the twenty-first day and leveled off, rising slightly to the twentyseventh day. Plasma $E$ gradually returned to normal in the same manner, but with some lag behind the whole blood value. This rise to normal with clinical improvement is in accord with the finding of Milhorat (8) in a case of nutritional deficiency and a case of pemphigus vulgaris. When the patient was seen in clinic, six weeks after the beginning of treatment, all values were normal.

Case 14, Number 163708,1 a seventy-nine year old American white woman, was admitted by Emergency on March 31, 1940. No history could be obtained, and the patient had no complaints. Subsequent conversation with 
her physician revealed an old history of pernicious anemia treated with "Lextron" orally. He had not seen the patient for three months.

Physical examination: The patient was a well-developed, fairly well nourished woman of seventy-nine, disoriented and confused, not appearing acutely ill. The temperature, pulse rate, respirations and blood pressure were normal. The fundi showed mild arteriosclerotic changes. The tongue was smooth and red. The heart was enlarged, with a systolic murmur. The liver was 1 finger's breadth below the costal margin. Lower tendon reflexes were absent; uppers, hyperactive and equal.

Laboratory data: Erythrocytes 1,320,000. Hemoglobin 5.0 grams. Leukocytes 3,550, with normal differential. Smear : marked anisocytosis, poikilocytosis, a few normoblasts and an occasional megaloblast. Hematocrit 17.4 per cent. Reticulocytes 0.2 per cent. Urine: urobilin positive. Stool negative. Blood Wassermann negative. Icterus index 12. Gastric analysis : no free $\mathrm{HCl}$ fasting, after alcohol and after histamine.

Course: On the first day the patient received $0.5 \mathrm{cc}$. of "Reticulogen" intramuscularly, and on the second and fourth days $1 \mathrm{cc}$. The red cell count and hematocrit rose until the nineteenth day when they leveled off at 3,300,000 and 35 per cent, respectively. Reticulocytes rose to 26 per cent on the fifth day and gradually fell. On the twenty-seventh day $1 \mathrm{cc}$. of “Reticulogen" was given. No further rise in hematocrit or red cell count was observed during the remainder of the patient's stay in the hospital. She was discharged to the care of her physician on May 9, 1940, with a diagnosis of pernicious anemia, generalized arteriosclerosis, senile dementia and arteriosclerotic heart disease.

When first seen, on admission, this patient had a significantly low plasma and whole blood $E$. On the second day there was a slight rise in the whole blood $E$ which was of questionable significance. For some reason, possibly relief of dehydration, the red cell count fell markedly during the first three days. The hematocrit did not change, and this would indicate that the M.C.V. changed markedly. The reticulocyte count on this day was 7 per cent, so that active regeneration had begun and the M.C.V. would be expected to rise. However, it seems possible that the red count may have been at fault, and this quick esterase response to therapy is open to doubt. On the subsequent days this patient followed much the same course as the first patient, until the nineteenth day, when the blood picture leveled off at 3,500,000 red cells and a hematocrit of 35 per cent. On the nineteenth day the whole blood $E$ was normal, the plasma $E$ was rising, the cell $E$ and M.C.E. were still high, with the M.C.E. leveling off before the other values. On the thirty-first day the whole blood and plasma $E$ had fallen, but the whole blood $E$ was still within the normal range. Cell $E$ and M.C.E. had fallen, but were still significantly high.

Case 15, Number 161604,1 a sixty-year old Russian Jewess, was admitted by Emergency on January 24, 1940. She had been bed-ridden for two weeks. Her diet had been very deficient. Recently she had noted the appearance of a yellow color in her skin. She complained of edema of the ankles, and coldness of the hands and feet. She had been treated "for anemia," but apparently had received no liver therapy in any form.

Physical examination: The patient was a well-developed, fairly well nourished woman of sixty, appearing prostrated, semi-comatose and pale, with a yellow color. The temperature, pulse, respirations and blood pressure were normal. The fundi were pale and showed small hemorrhages. The heart was enlarged, with a systolic murmur. The liver was 2 finger's breadth below the costal margin. Neurological examination was negative.

Laboratory data: Erythrocytes 900,000. Hemoglobin 4.4 grams. Leukocytes 5,800 with normal differential. Smear: marked poikilocytosis, anisocytosis and basophilia, with some nucleated red cells. Hematocrit 13.0 per cent. Reticulocytes 2.4 per cent. Urine and stool negative. Blood Wassermann negative.

Course: During the first six days the patient was given 6 cc. of "Reticulogen" intramuscularly, and from this time to the fourteenth day, 0.5 cc. daily. Clinical improvement paralleled improvement in the blood picture and the patient was discharged to a nursing home on February 8, 1940, with a red cell count of 2,730,000, 7.9 grams of hemoglobin, and a hematocrit of 29.8 per cent. Discharge diagnosis was pernicious anemia and generalized arteriosclerosis.

When first seen, twelve hours after treatment was started, this patient had esterase values comparable with those of Case 14. During the two weeks of treatment, the whole blood $E$ rose but did not reach the normal range; the plasma $E$ fell, but the fall is probably not significant. The cell $E$ and M.C.E. were normal at first and rose in a similar fashion to those of the first two patients. A tendency toward leveling off is seen in the M.C.E. values. This case is of little value in itself, and merely serves to corroborate the findings on the first two.

Data on the three pernicious anemia patients are given in Table II. 
TABLE II

Choline esterase changes occurring during the treatment of pernicious anemia

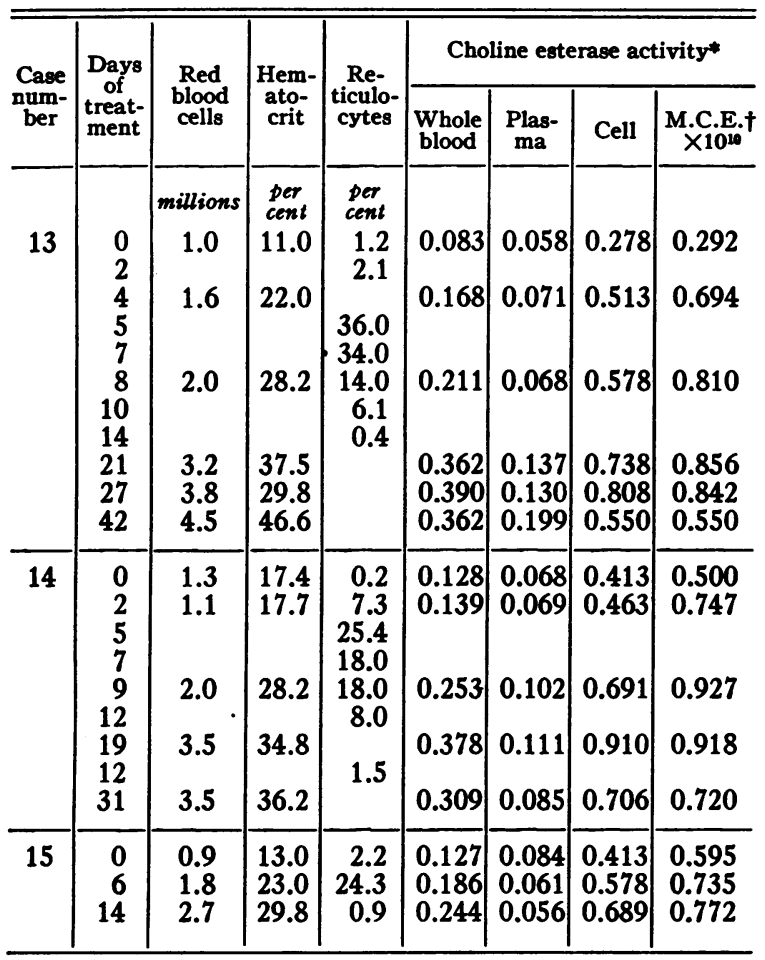

* Choline esterase activity $(E)$ is expressed as cc. of $0.01 \mathrm{~N} \mathrm{NaOH}$ required to neutralize the acetic acid formed from acetyl choline per minute per cc. of blood, plasma or cells at $\mathrm{pH} 7.65$ and temperature $25^{\circ} \mathrm{C}$.

$\dagger$ M.C.E. (the esterase activity per cell) is found by multiplying the cell $E$ by the M.C.V. in cc. This value is expressed multiplied by $10^{10}$.

\section{DISCUSSION}

There appears to be a mechanism whereby the choline esterase activity and distribution between the cells and plasma are altered under certain conditions of anemia. No change in whole blood or plasma esterase was observed in cases with a hematocrit of more than 30 per cent. Since most of the moderately anemic cases were microcytic, and tended to have normal red cell counts, with low hematocrits, the effect of lowering the red cell count alone cannot be observed in this series. In all cases with hematocrit 25 per cent or less, and with red blood cell count $2,270,000$ or less, there was a significant lowering of the esterase values for both plasma and whole blood. The whole blood values, although low, are higher than the values which would be expected if the cell esterase remained normal. There occurs what may be termed, for purposes of discussion, a compensa- tion for the reduced plasma esterase and the reduced number or total volume of circulating cells. The amount of this compensation was in a general way related to the condition of the patient. The best response was seen in the two acute hemorrhage cases, where the bone marrow was presumably normal and had not been subjected to prolonged drains upon its resources, and in pernicious anemia patients after treatment was started and before restoration of the blood picture was complete. All of these cases showed a good reticulocyte response at the same time as the esterase response. One might naturally suppose that the increase in cell esterase was associated entirely with the appearance of reticulocytes in large numbers in the circulating blood. However, it was seen that the two cases of chronic leukemia, with no rise in reticulocyte count, and with anemia of long standing, showed almost equally high esterase activity of the cells. Unless an increased blood destruction in leukemia is postulated, it is impossible to conclude that the high esterase activity of the cells is related entirely to their youth. It seems more probable that there is some mechanism for maintaining a high esterase in the mature cells under conditions of anemia, and that the mechanism fails in the very debilitated or moribund patient, or when the marrow fails seriously.

An explanation of the changes in cell esterase on a basis of surface area of the cells is untenable. Although several of the cases exhibiting elevated mean corpuscular esterase had large cells, some with very high mean corpuscular volumes, e.g., untreated pernicious anemia, showed very low mean corpuscular esterase. Also a case of microcytic anemia had an elevated mean corpuscular esterase. No correlation existed between M.C.V. and M.C.E. in this series.

The pernicious anemia patients, before treatment, appeared to be unable to make this compensation. By far the lowest cell esterase and whole blood esterase values were seen in these patients, and the fact that immediately upon treatment these values rose strikingly suggests the possibility that in pernicious anemia there is a specific inability to put out choline esterase in adequate amounts in such cells as the marrow produces.

In Case 14, there was, for some unknown reason, a leveling off in the response of the blood 
picture on treatment. It may be that the therapy was inadequate. With this leveling off came a drop in plasma esterase, which had been rising gradually while the blood picture was improving. There was also a fall in the cell $E$ and M.C.E., which appears similar to the return to normal in Case 13. There is a possibility, however, that this fall represents the beginning of a reversion to the untreated condition. No definite conclusion can, of course, be drawn from a single sample on a single case, but the suggestion can be made that accompanying the arrest in blood picture improvement there may have been some sort of deficiency or inhibition in the choline esterase mechanism which is responsible for this fall.

With the return to a normal blood picture there is a reduction in the esterase activity of the cells of the pernicious anemia patient to the normal level. The period of recovery lasted about six weeks, or somewhat less than the average life of a normal red blood cell. This reduction to normal might be thought to occur simply as the average age of the circulating cells increased. It appears from the leukemia picture, however, that this is probably not the explanation. And since low serum esterase has been reported in acute hemolytic icterus (7), in the face of massive blood destruction, it does not seem probable that blood destruction is the mechanism for removing the esterase from the cells into the plasma. How the reduction is controlled and what the mechanism is whereby cells lose and the plasma gains esterase activity are unexplained.

It seems possible, in some of the cases, that the mechanism of the reduction in plasma esterase might be simple dilution. When the plasma values are corrected for dilution occurring with the restoration of the blood volume following hemorrhage in Cases 1 and 2, normal values are obtained. But when such a correction is made in the other cases, where the relative plasma volume was chronically high, most of the values are still low. Low values have also been reported in a number of non-anemic conditions, and it seems improbable that plasma dilution can be the explanation.

The studies of Alles and Hawes (11) indicate that blood cell choline esterase may be qualitatively different from plasma choline esterase. They found that at relatively low substrate concentrations the activity of the cells was far greater than that of the plasma, but that inhibition of the cell esterase occurred at higher substrate concentrations. This work appeared after the present investigations were completed. Figure 2 in their studies indicates that the substrate concentration chosen was such as to give a maximum of cell esterase activity. They also found a marked effect of $\mathrm{NaCl}$, a certain concentration being required for maximum activity. This aspect of the condition of anemias must be investigated, although it is known that some of the patients had normal blood chlorides, and there was no clinical reason for supposing that any except possibly the acute hemorrhage cases might have had disturbed $\mathrm{NaCl}$ balances. The changes observed in cell esterase are not readily explained on a basis of $\mathrm{NaCl}$ effects, and it seems improbable in this particular series, where the changes we are most concerned with are marked increases over the normal rather than decreases, that the $\mathrm{NaCl}$ factor is a determining one.

A recent paper of Nachmansohn (18) shows that divalent cations have marked effects on the activity of choline esterase. The possible significance of these ions in the anemia choline esterase picture with special reference to $\mathrm{Mg}^{++}$is being investigated in collaboration with the Department of Medicine of this university. Other studies which are planned include investigations on animals of the choline esterase distribution and variations under conditions of anemia and blood destruction, studies on the bone marrow esterase, and investigations of the properties of the cells of anemic patients with regard to choline esterase.

\section{SUMMARY}

1. Choline esterase determinations were made on whole blood and plasma of normal persons and of patients with various blood dyscrasias and anemias. Values for the cells were calculated.

2. The findings on esterase activity of the plasma were in accord with those of others, and consisted of a lowering of plasma esterase in conditions of debilitation, in this instance associated with severe anemia.

3. In patients with anemias other than severe, untreated pernicious anemia, who were in fair clinical condition or whose bone marrow was relatively free of pathology, there occurred a marked rise in the esterase activity of the cells. This high 
level of activity in the cells is thought not to be wholly dependent upon the presence of reticulocytes and young cells in the circulating blood.

4. The cases of untreated, severe pernicious anemia showed a marked reduction in esterase both of the cells and the plasma. On treatment there was an immediate sharp rise in the cell esterase to a strikingly high value. This high esterase activity was maintained for a time, but gradually fell off to normal as the blood picture was restored to normal. The plasma esterase rose slowly and steadily to normal.

5. It is suggested that some mechanism exists for maintaining a high esterase in the cells in conditions of anemia; that this mechanism fails in severe, untreated pernicious anemia, in extreme debilitation and/or in severe bone marrow failure, and is stimulated or rehabilitated in the pernicious anemia patient on treatment with liver therapy. It is also suggested that some mechanism exists for reducing the high cell esterase to normal with the restoration of the blood picture to normal, and that this restoration is something more than a simple liberation of the enzyme by cell destruction.

I should like to express my gratitude to Dr. W. O. Fenn for his valuable suggestions and encouragement; to Dr. Sidney C. Madden and Mr. Albert P. Rowe for their cooperation in supplying blood samples from their dogs; and to Dr. John S. Lawrence and the members of the medical and pediatric staffs for their interest and cooperation in giving me access to the patients on their services, which made this work possible.

\section{BIBLIOGRAPHY}

1. Galehr, O., and Plattner, F., Uber das Schicksal des Acetylcholins im Blute. Arch. f. d. ges. Physiol., 1928, 218, 488.

2. Matthes, $K$., The action of blood on acetylcholine. J. Physiol., 1930, 70, 338.
3. Ammon, R., and Voss, G., Die acetylcholinzerstörende Wirkung des Blutes. Arch. f. d. ges. Physiol., $1935,235,393$.

4. Stedman, E., and Stedman, E., The relative cholineesterase activities of serum and corpuscles from the blood of certain species. Biochem. J., 1935, 29, 2107.

5. Stedman, E., and Russell, W. R., The choline-esterase content of blood in myasthenia gravis. Biochem. J., 1937, 31, 1987.

6. Ginsberg, R., Kohn, R., and Necheles, H., Studies on the blood esterase. Am. J. Digest. Dis. and Nutrition, 1937, 4, 154.

7. Antopol, W., Schifrin, A., and Tuchman, L., Decreased choline esterase activity of serum in jaundice and in biliary disease. Proc. Soc. Exper. Biol. and Med., 1938, 38, 363.

8. Milhorat, A. T., The choline-esterase activity of the blood serum in disease. J. Clin. Invest., 1938, 17, 649.

9. Glick, D., Properties of choline esterase in human serum. Biochem. J., 1937, 31, 521.

10. Stedman, E., Stedman, E., and Easson, L. H., Cholineesterase. An enzyme present in the blood serum of the horse. Biochem. J., 1932, 26, 2056.

11. Alles, G. A., and Hawes, R. C., Cholinesterases in the blood of man. J. Biol. Chem., 1940, 133, 375.

12. Mendel, B., Mundell, D., and Strelitz, F., Cholinesterase and electrolytes. Nature, 1939, 144, 479.

13. Vahlquist, B., On the esterase activity of human blood plasma. Skandinav. Arch. f. Physiol., 1935, 72, 133.

14. Hall, G. E., and Ettinger, G. H., Effect of regular injections of acetylcholine upon the cholineesterase activity of the serum. J. Pharmacol. and Exper. Therap., 1937, 59, 29.

15. Antopol, W., Tuchman, L., and Schifrin, A., Cholineesterase activity of human sera, with special reference to hyperthyroidism. Proc. Soc. Exper. Biol. and Med., 1937, 36, 46.

16. Ammon, R., Die fermentative Spaltung des Acetylcholins. Arch. f. d. ges. Physiol., 1933, 233, 486.

17. Fisher, R. A., Statistical Methods for Research Workers. Oliver and Boyd, Edinburgh and London, 1938, 7th Ed.

18. Nachmansohn, D., Action of ions on choline esterase. Nature, 1940, 145, 513. 